IZADP No. 2644

The Polish Wage Inequality Explosion

Andrew Newell

Mieczyslaw W. Socha

February 2007 


\title{
The Polish Wage Inequality Explosion
}

\author{
Andrew Newell \\ University of Sussex \\ and IZA
}

\author{
Mieczyslaw W. Socha \\ University of Warsaw
}

\author{
Discussion Paper No. 2644 \\ February 2007
}

\author{
IZA \\ P.O. Box 7240 \\ 53072 Bonn \\ Germany \\ Phone: +49-228-3894-0 \\ Fax: +49-228-3894-180 \\ E-mail: iza@iza.org
}

\begin{abstract}
Any opinions expressed here are those of the author(s) and not those of the institute. Research disseminated by IZA may include views on policy, but the institute itself takes no institutional policy positions.

The Institute for the Study of Labor (IZA) in Bonn is a local and virtual international research center and a place of communication between science, politics and business. IZA is an independent nonprofit company supported by Deutsche Post World Net. The center is associated with the University of Bonn and offers a stimulating research environment through its research networks, research support, and visitors and doctoral programs. IZA engages in (i) original and internationally competitive research in all fields of labor economics, (ii) development of policy concepts, and (iii) dissemination of research results and concepts to the interested public.
\end{abstract}

IZA Discussion Papers often represent preliminary work and are circulated to encourage discussion. Citation of such a paper should account for its provisional character. A revised version may be available directly from the author. 
IZA Discussion Paper No. 2644

February 2007

\section{ABSTRACT}

\section{The Polish Wage Inequality Explosion}

This paper presents and analyses the sharp increase in hourly wage inequality after 1998 in Poland. The increase was similar in magnitude to the much-studied increase in British wage inequality during the 1980s. Using data from the Polish Labour Force Survey, we find this increase to be associated with rising wage differentials and within-group variances at both the upper and lower ends of the wage distribution. These increases are associated with differences in wage-setting patterns between the public and private sector as well in the rapid increase in the demand for educated labour. One important difference between the sectors is the lack of an impact of local labour market conditions, or wage curve, clearly evident in private sector wages, on public sector wages.

JEL Classification: J31, P23

Keywords: Poland, wage inequality

Corresponding author:

Andrew Newell

Department of Economics

University of Sussex

Falmer, Brighton BN1 9QN

United Kingdom

E-mail: a.t.newell@sussex.ac.uk 


\title{
The Polish wage inequality explosion
}

\author{
Andrew Newell and Mieczyslaw W. Socha
}

\section{Introduction}

There has been a large, well documented rise in wage inequality in most of the transition countries over that last 15 years or so, see Table 1 and Milanovic (1999), for instance. This paper presents the longer term progress of wage inequality in Poland using data from successive sweeps of the Polish Labour Force Survey (PLFS). Our analysis complements and extends previous work, such as Rutkowski (1996), Keane and Prasad (2002) and Newell and Socha (2005). We find that Polish hourly wage inequality expanded 1993-2004 by between 10 and 20 percent, depending on the measure. However, hourly wages almost all of this growth took place between 1998 and 2002. We find a rise from 0.43 to 0.51 in the standard deviation of log hourly wages of employees over this short period ${ }^{1}$. This is a large increase. For comparison, the much-discussed rise in the standard deviation of log hourly wages in Britain 1980-1990 was from 0.45 to 0.56 .

Much happened in Poland's labour market from 1998 to 2002. The private sector expanded to over half of employment. Production industries (agriculture, mining and manufacturing) continued to decline in importance for jobs. The share of the working age population with university degrees increased rapidly and the share with only primary education continued to fall. There was a major recession in employment as the rapid GDP growth of the late 1990s slowed down. There were tax and social security payment reforms as well as a decline in the minimum wage relative to the median. All of these events might be related to widening wage inequality. As we report later in this introduction our data do not allow detailed work in the impact of these policy changes, but we will show that the data are consistent with a combined impact of privatisation, rising demand for skill and the recession being the likely causes of the rise in wage inequality.

Section 2 discusses the data. Our data source, the PLFS, has shortcomings that might distort the picture of wage inequality. The data are quite heavily rounded and there is a drop in the response rate to the question on wages from $82 \%$ to $73 \%$ between 1998 and 2002. Our work, reported in Section 2, suggests that these shortcomings, though serious, do not invalidate the use of these data.

Section 3 discussed the rise in wage inequality in detail provides an overview of the main possible causes. Section 4 presents a sequence of regression results which investigate the determinants of wages in Poland over the period. We use these results to decompose the rise in wage inequality, as measured by the change in the standard deviation of log hourly earnings. Section 5 concludes.

\footnotetext{
${ }^{1}$ We employ the standard deviation of log wages and, to a lesser extent, the Gini coefficient, as measures of wage variation or inequality. We de-emphasise measures based on quantiles because the wage data contain rounding errors, see Section 2.1.
} 
We find that the increase in wage inequality 1998-2002 was associated with rapidly rising returns to education for highly-qualified workers in highly-skilled occupations and falling relative wages for those with only primary education. Rising within-skill group wage variance was also concentrated and the upper and lower ends of the wage distribution. This is associated with privatisation and an increase in the share of young people in some low-paying occupations. There is a clear contrast between the private and public sectors in the impact of local labour market conditions on wages. In short, these are non-existent in the public sector but strong in the private sector data. This offers a partial insight into why the variance of wages is higher in the private sector.

\section{The PLFS earnings data}

Since 1993 the PLFS has asked respondents to reveal their earnings net of deductions in the previous month. Some summary statistics from responses are given in Table 2. There is a clear and steady increase, 1998-2002, in monthly take-home pay inequality, as measured by the Gini coefficient, or by the standard deviation of log wages. Before we begin an analysis of this increase, two shortcomings of these data need to be discussed. First, since they are derived from the memories of individual respondents, they are highly rounded. Secondly, there is a sharp decline in the response rate to this wage question over the period. We also discuss the impact on the wage distribution of adjusting for hours worked to create a measure of hourly earnings.

2.1 Rounding errors. First note how, in Table 2, the decile ratio statistics show a less definite trend than the Gini, for instance. The reason for this is in the nature of the responses to the wage question. There are large spikes of density at round numbers, such as 500 and 1000. Table 3 illustrates this. It is very likely this phenomenon is partly driven by vagueness in recollections of monthly wages, given that interviews took place in the home, see Popinski (2006). These rounding errors will impact on quantile-based measures of inequality. One consequence, for instance, might be that the wage at a given percentile does not change from one period to the next, despite actual money wage growth ${ }^{2}$. Because of this potential problem we don't use percentile-based measures of wage inequality in this study.

It is unlikely a priori that the rise in wage variance is due in any major part to a change in rounding error variance. To see this note that since rounding errors by their nature are proportional to the true wage, the relationship between the variances of recorded and true $\log$ wages is:

$$
\operatorname{var}\left(w_{\text {recorded }}\right) \cong \operatorname{var}\left(w_{\text {true }}\right)+\operatorname{var}(\text { error })+2 \operatorname{Cov}\left(w_{\text {true }} \text {, error }\right) \text {. }
$$

Firstly, we can think of no particular reason why log wages and proportional measurement errors should covary much, so the third term in the above expression seems likely to be small. More importantly we cannot think of reasons why measurement errors should either suddenly increase in variance or suddenly start to

\footnotetext{
${ }^{2}$ Of course, it might also jump up or down, but either way changes in decile ratios can be distorted by errors.
} 
covary with wages at the turn of the century. We offer three pieces of evidence, all negative, on the hypothesis that rounding errors contribute importantly of the increase in wage variance. Firstly, we created counterfactual, non-spiked wage distributions ${ }^{3}$ in two different ways, but the growth in their variances over time were as large as those in the raw data. Secondly, the range of spikes containing 95\% of reported wages increases dramatically from 1998-2002 (1998 range $=1000 \mathrm{zl}, 2002$ range $=$ $1500 \mathrm{zl}$ ). Again, this suggests a genuine increase in wage variance. Lastly, and perhaps most tellingly, the regression work in later sections shows no increase in the proportion of unexplained wage variation in the later data sets. We conclude from these results that it is unlikely that the rise in wage variance was importantly caused by a rise in rounding errors.

2.2 Changes in hours worked. One reason for the increased variance of monthly wages could simply be an increase in non-standard working hours, see Table 4. Since 1998 the incidence of part-time working and of workers who work very long hours have both increase markedly. This increase the diversity of hours has been noted by the commentators, see OECD (2004). If we adjust the monthly wages for hours worked, to create an estimated hourly wage measure it becomes clear that the increased variation in hours is not at the heart of the increase in monthly wage variance. Table 5 shows a clear and substantial increase in diversity in hourly wages. These hourly wages are our calculations using the monthly wage data of PLFS and responses to a question on weekly hours. The increase in hourly wage variance is similar in size to that of monthly wages; slightly greater in the Gini coefficient and slightly smaller in the standard deviation of log wages.

It is notable from Table 5 that almost all of the increase in hourly wage variation 1993-2004 happens between 1998 and 2001/2. Because of this, much of our analysis is focused upon this shorter period. Chart 1 plots frequency distributions for log hourly wages in the Autumn 1998 and Spring 2002 rounds of the PLFS. Note that the plots are not as smooth as we might expect, as spikes caused by rounded wages create undulations in the upper parts of the distributions. However, the greater variance of the 2002 data is visible.

2.3 Declining wage reporting. There was a fall between 1998 and 2002 in the proportion of employees in the PLFS who give an answer to the wage question. In the 1998 survey 82\% of employees report a wage. This fraction drops to $73 \%$ by 2002 . Could this change in reporting bias be a major source of the apparent change in variance? We approach this question two ways. First we study the conditions under which this would happen, and see if they are met, and second we construct counterfactual wage distributions.

In principle, the impact of an increase in non-reporting upon reported wage variance depends (a) upon whether potential non-reporters have a different wage variance than reporters, and (b) upon the size of the wage gap between the two groups. If potential non-reporters have a higher wage variance, then if fewer of them report wages, reported wage variance will fall, as long as the reporters are a majority in the sample. If potential non-reporters have a smaller wage variance, the effect of increasing

\footnotetext{
${ }^{3}$ For instance, we fitted smoothed distributions through the data. We also added shocks to the wages at the rounding spikes.
} 
reportage is unclear. The equation below gives why. Subscript $R$ denotes reported, $U$ is for unreported. $S$ is the fraction of workers who report wages. $V$ is the true variance.

$$
\begin{aligned}
& V_{R}=\frac{1}{S}\left[V-(1-S) V_{U}-S(1-S)\left(\bar{W}_{R}-\bar{W}_{U}\right)^{2}\right] \\
& \partial V_{R} / \partial S=\frac{1}{S}\left[V_{U}-V_{R}\right]+\frac{2 S-1}{S}\left(\bar{W}_{R}-\bar{W}_{U}\right)^{2}
\end{aligned}
$$

To illustrate, if older, better qualified workers, a group with intrinsically high wage variance, are less likely to report their wages, it is very likely that $V_{U}>V_{R}$, so that a fall in reporting should lower wage variance.

Table 6 shows how the increase in non-reporting is indeed somewhat concentrated among professional, managerial and university-educated employees. Table 7 gives wage gaps and wage variances by occupation, level of completed education and sector. Profession, managerial and technical employees experienced large increases in wage variance. It seems, than, that an increase in non-reporting is more likely to lower reported wage variance than increase it.

Table 8 gives the standard deviations of actual and counterfactual wages for 1998 and 2002. The counterfactual distributions are calculated by re-weighting groups of workers with their proportions among employees. The changes in the wage distribution are quite small, but the change 1998-2002 in the counterfactual variance is larger than that calculated without adjustment. This is evidence against the hypothesis that a change in wage reporting behaviour is an important cause of the rise in inequality.

In summary, the PLFS wage data suffer from three imperfections for this study: they are rounded, they refer to monthly wages and they suffer from changes in nonreporting. None of these disadvantages is likely to be responsible for a significant part of the increase in hourly wage variance.

\section{What caused the explosion in wage inequality?}

We start this section by pointing out some features of the rise in inequality. Table 7 presents some of the components of the variance of wages. First note large increases in the size of the gaps between the overall mean and means for managerial and technical occupations and primary-educated employees. Clearly skilled white collar occupations are becoming better-paid and primary educated workers are losing out on average. Secondly, as already noted, Table 7 shows large increases in within-group wage variance for professional, managerial, university-educated and primaryeducated employees. Thirdly, Table 7 also shows that the rise was not a straightforward mechanical impact of the movement of jobs into the (higher variance) private sector, since the variance of wages increases markedly in both the public sector and the private sector. Thus the variance and relative wage changes by occupation and completed education are consistent with the statistics in Table 9, which show that both tails of the hourly wage distribution are estimated to have thickened over the period 1998-2002. If we decompose the change 1998-2002 in the hourly wage variance by education groups, we find that the changes in relative pay 
and within-group variance for two groups, university-educated and the primaryeducated workers account for $52 \%$ of the increase in wage variance, despite being only about $25 \%$ of employees. Similarly if the change in wage variance is decomposed by occupation, professional and managerial workers account for $25 \%$ of the increase in wage variation, despite being only $16 \%$ of employees.

Now let us turn to the shifting characteristics of employees over the period. First, Table 10 gives the evolution of the educational and demographic structure of the population. Participation in the labour market fell throughout the period. The employment to population ratio fell heavily, about 4 percentage points between 1998 and 2002. The long-run trend towards higher levels of education is also quite marked, with a rise in the share of workers with qualifications above secondary level, particularly graduates, and a fall in the share of those with no more than primary education. Thirdly, there is a decline in the proportion of married people in the survey, which is probably due in part to the longer time young people are spending in education. Lastly one demographic effects is mildly evident: the early 1980s baby boomers move into their 20s.

Next, Table 11 gives descriptive statistics for employees 1994-2004. The share of married people in employment fell. The proportion of employees with university education increased; indeed it increased more rapidly than in the population of working age in general. There is a decline in the number of employees with no more than lower vocational education. Thus there has been a great rise in the relative wages and relative employment of better-educated workers as well as in their share in the population of working age. This obviously reflects the shift in relative demand for skilled labour that has happened at a great pace in most of the transition countries. It is tempting to guess that this shift could be enough in itself to explain the increase in wage variance. But the majority of the increased wage variance is within occupational or educational groups, as Table 7 illustrates, so there is more to the rise in inequality than a shift in relative demand for broad skill categories.

Among industries, the manual-intensive sectors: agriculture, mining and manufacturing have mostly declined in relative importance. The share of workers in construction has followed a cyclical path: booming in the late 1990s and falling after 1999. The growing sectors are trade and repair and financial services.

The private sector has, of course, grown massively as an employer, though sales of publicly-owned enterprises, the starting-up of new firms and inward investment. Note also there is a decline in the proportion of workers employed in large firms. Among occupations, the share of skilled manuals has declined, while the shares of professional and sales workers have increased; otherwise the changes are relatively small.

In Table 11, the period between 1998 and 2002, during which the variance of wage seems to have increased the most, seems typical inasmuch as the trends visible from comparisons for 1998 with 1994 seem to carry on. There is rapid privatisation, for instance, but no more so than during the period from 1994-1998. What happened in 1998-2002 that might have raised wage inequality? 
3.1. Minimum wages. Between 1998 and 2002, the minimum wage fell from about $40 \%$ to about $35 \%$ of the average gross wage. Since the PLFS data are estimates of wages net of taxation and taxes themselves were changing, the exact impact of changes in minimum wage legislation on their distribution cannot be studied directly. Nonetheless a declining minimum wage is consistent with the expansion in the lower tail of the wage distribution.

3.2 Tax and social security payment changes. One major change in the system of labour taxation was linked to the social security and health care systems reforms that came into force in 1999. The reform did not changed the total rate of social contribution but introduced a division between employers' and employees' contributions. The second relevant tax change over the period was a reduction in 1999 of the three main marginal tax rates, from 21, 33 and 45 percent to 19, 30 and 40 percent. How might such tax changes impact upon the wage distribution? In theory, the social security reform should be neutral, if the relevant tax wedges are unchanged. Of course, if employers did not pass over the tax savings, then employees would have been worse off. The impact on the gross, or before-tax, wage distribution of this pattern of reduced marginal tax rates is ambiguous even the simplest model.

3.3 Privatisation. Of course the privatisation of existing enterprises and the creation of de novo firms have been the driving forces behind the structural transformation of the Polish labour market. Why, in principle, might privatisation matter for the wage distribution? Newell and Socha (2005) showed, as we shall below, that private sector firms pay less at the low end of the wage spectrum and more at the top end. Why might this be? One simple answer is that the public sector is more unionised and unions usually prefer egalitarian wage structures. Of course this begs 2 questions: (1) why is the private sector less unionised and (2) why should unions prefer wage equality. In Poland the answer to (1) is probably a historical legacy. New private sector firms are often small and small firms where employers and employees work together are notoriously hard to unionise. The answer to (2) is usually couched in terms of the games skilled labour must play to gain solidarity from less-skilled workers in wage bargaining. Unions might not be the only source of more equal public sector pay. It simply be that managers in private firms have more incentive to learn about workers' abilities and pay them accordingly. It is also possible that because of political accountability public sector managers are discouraged from paying either very high wages or very low wages. There are more prosaic possibilities which would lead to greater private sector pay inequality, such as differences in the use of performance-related or profit-related pay, There is a perception in Poland, for instance, that foreign-owned firms tend to pay especially well to high-skilled workers, but very poorly for low-skilled workers. Unfortunately our data do not allow us to examine this hypothesis.

3.4 Local labour market conditions. Poland's unemployment has a strongly persistent regional pattern, which broadly survived the 1999-2003 recession. after a period of economic growth in the late 1990s, there was a large fall in total employment of around 1.5 million jobs, beginning in early 1999, reaching a low point in 2002/3. A revival of employment began in 2004. This macroeconomic cycle was reflected in a rise in unemployment that persisted beyond first half of the decade. The causes of recession in employment were a combination of negative external macroeconomic shocks, a tightening of domestic monetary policy and industrial restructuring. This 
employment cycle might have raised the variance of wages if, for instance unemployment affects the wages of low-paid workers more than high-paid workers. Since a business downturn often affects low-skilled workers more than the higherskilled, this wage effect is quite possible.

\section{Empirical Analysis}

Next we turn to regression analysis. The first goal is to establish whether the increase in hourly earnings variation can be explained by conventional augmented Mincer variables, and if so, which variables. Initially we estimate by Ordinary Least Squares, that is, without attempting to control for biases due to participation and wage reporting. Table 12 gives estimates for four rounds of the PLFS that span the decade. Here and elsewhere we control separately for workers reporting short and long hours. This is because we estimate hourly earnings by dividing monthly earnings by weekly hours worked. This leads inevitably to measurement errors since monthly hours are likely to vary less than weekly hours. As well as this, many workers on monthly pay are paid according to normal hours, rather than actual hours. We do not have estimates of normal hours for the earlier rounds of the PLFS, so for consistency over time we employ data on actual hours in calulating hourly wages.

Turning to the results, first note that there is no deterioration over time in the goodness-of-fit of these equations. In the data from the early part of the current decade, these equations fit just as well, if not a little better, than they do on the 90s datasets. Standard errors do increase, though, since the proportion of the variance accounted for by this set of explanatory variables is fairly steady over time.

Note first that the wage premium to being married, usually understood as a reflection of unmeasured productivity characteristics, rises over time. Wage premia for education $^{4}$ also rise over time, quite uniformly. In other words, the wage penalty to having only primary education is becomes larger. It may seem surprising that the premia do not fan out. However, note these are effectively within-occupation premia. If we omit occupational controls, the premia to higher levels of education rise more steeply. These rises are reflected in our estimates in the very strong rises of the premia to professional, managerial and technical occupations ${ }^{5}$. Thus, between 1998 and 2002, for instance, university and secondary educated managerial and professional workers experience a cet. par. wage increase of thirteen log points compared to a skilled manual worker with lower vocational education. Similarly, a sales or unskilled worker with only primary education experiences six or seven log point deterioration of their wage position with respect to the same skilled manuals. Thus the parameter movements deliver widening wage differentials.

Next, industrial wage premia do not show much in the way of systematic change over time. This means that at this level of industrial aggregation, we cannot identify which sectors might be driving the change in inequality. The other parameters that do move over time are those for the private sector and those relating to experience and tenure. The private sector premium, positive and significant in the 1990s data sets, becomes

\footnotetext{
${ }^{4}$ The default group are those with only primary-level education. Note also that the results for 2002 seem a little out of line with the overall trend. This may be a seasonal effect, as this is is the only Spring survey dataset included in the study.

${ }^{5}$ Here the default group are skilled manual workers.
} 
insignificant in the 2000s data sets, perhaps because of the expansion of the private sector through the labour market. The premia to experience rise but flattens, while the return to year of tenure rises and steepens. The total effect is towards greater inequality.

Additionally, there is a well-defined and positive firm size effect on wages. Lastly, urban regions and regions with lower unemployment tend to have higher wages, and the effect of regional unemployment appears to grow over time. This is related to privatisation, see late in this section.

Next we investigate whether the changes over time in estimated parameters are due to changes in sampling biases. There are several potential sources of bias. First, there are the familiar participation and employment selection biases. We have seen that the participation rate and the employment to population ratio have changed markedly over the decade, so if there are parameter biases due to selection into job-holding, these may have shifted over time and may partly explain the changes in parameters we observe.

There is another potential bias due to the fact, discussed above, that not all employees revealed their earnings to the PLFS interviewers. In particular, white-collar workers, such as managers and clerical workers, were significantly less likely to report wages and this tendency increased over time. In principle, these three sources of bias that we might call the participation, labour force status and non-reporting biases could be dealt with separately. Without much relevant household information, we have no potential instruments for participation, so we are forced to collapse the three steps of selection into a single step and model what makes someone report their wage, as distinct from being a non-reporter. We estimate this joint wage reporting and wage determination system for the 1998 and 2002 samples. These two samples more-orless mark the beginning and the end of the rise in wage inequality. We model participation as depending on individual characteristics, such as education, age, gender, household and marital status as well as two potentially relevant regional characteristics, the degree of urbanisation and the unemployment rate.

To identify the participation/reporting equation, with little household information at our disposal, we use age and gender interacted plus a variable that helps identify employees who do not report wages. To explain, in later rounds of the survey, respondents are allowed to record an uncertain response, such as 'don't know', to the question about how many people work at their workplace. In earlier rounds only definite answers were allowed. We create an indicator variable called vague that takes the value 1 when a respondent is uncertain about firm size, and zero otherwise. Our hypothesis is that if a respondent is uncertain about the size of the firm, they also may not recall their wage, either out of genuine ignorance or because of an unwillingness fully to engage with the survey.

The results are given in Table 13. The Heckman correction term is significant, as is the vague variable. However, the wage equation parameters for both years are very similar to the results of Table 12, so the changes in parameters are also very similar.

In the absence of being able to provide evidence that the parameter changes 19982002 are due to shifting sampling biases, our next experiment is to adapt the 
technique of Blinder-Oaxaca decomposition to a variance decomposition as first suggested by Freeman (1982). Since the variance of the dependent variable of an OLS regression can be decomposed into explained and unexplained components, it follows that if we take two regressions the difference in variance is the sum of the differences in explained and unexplained components. If the same set of $\mathrm{X}$ variables are used in both regressions, then the explained component can be written as the sum of a change due to changes in coefficients and a change due to shifts in the $\mathrm{X}$ variable. In standard notation, the difference in the explained component is decomposed as

$$
b_{2}^{\prime} X_{2}^{\prime} X_{2} b_{2}-b_{1}^{\prime} X_{1}^{\prime} X_{1} b_{1}=\left[b_{2}^{\prime} X_{1}^{\prime} X_{1} b_{2}-b_{1}^{\prime} X_{1}^{\prime} X_{1} b_{1}\right]+\left[b_{2}^{\prime} X_{2}^{\prime} X_{2} b_{2}-b_{2}^{\prime} X_{1}^{\prime} X_{1} b_{2}\right]
$$

Table 14 decomposes the change in the log hourly wage variance for 1994-1998 and for 1998-2002. Of the 7.36 percentage point increase in wage variance 1998-2002, 4.07 points are due to shifting coefficients, as discussed above and -1.30 due to characteristics while 4.58 percentage points are unexplained by variables we employ. In other words, the changing characteristics of (wage-reporting) workers tended to reduce variance, while the increasing returns to education, senior white-collar occupations, experience and tenure have increased the variance of wages.

Though this procedure offers some useful insights, it leaves quite a lot of the increase in wage variance in the OLS residuals. We tried three methods of furthering our understanding. First, we investigated if there were systematic differences in the increases in residual variance among groups of workers defined by occupation and education. To do this, we collected the residuals from the 1998 and 2002 regressions reported in Table 12. Then, for each data set we calculated the standard error of these residuals for each of twenty educational/occupational groups ${ }^{6}$. We also collected changes in average characteristics for each of these groups. Then we ran a regression attempting to explain the pattern in the rises, 1998-2002, of the standard deviation in log wages across these groups of workers. After a little specification searching, we found the equation reported in Table 15. This regression tells us that increases in residual standard deviation are associated positively with increases in the share of young workers in the group, but also with the private sector's share in the group and the share of women in the group. A note of caution is due here. The sample is small. this result is driven by two groups whose share of young workers and residual wage variance grew the fastest. These groups were primary-educated sales workers, predominantly women, and primary-educated skilled manuals, predominantly men. Both groups are predominantly in the private sector.

The second way we investigated the increased OLS residual variance is by estimating quantile regressions. If the impact on wages of any characteristic, education for instance, varies over the wage spectrum, then this variation increases the residual variation of OLS estimation. In Table 16 we report the results of an investigation of this issue, via the estimation of quantile regressions ${ }^{7}$ for the November 1998 and spring 2002 PLFS rounds. Estimates at the $10^{\text {th }}, 25^{\text {th }}, 50^{\text {th }}, 75^{\text {th }}$ and $90^{\text {th }}$ quantiles are reported. The main results are as follows. First, the female wage disadvantage

\footnotetext{
${ }^{6}$ Groups were of the form: university-educated professionals, university-educated managers, secondary-educated managers, ..., primary-educated sales workers,..., and so on.

${ }^{7}$ See Koenker and Hallock (2001) for an excellent introduction to quantile regression.
} 
widens as we move up the wage distribution. This result is familiar in transition countries; see for instance Newell and Reilly (2001). Secondly, the returns to university, post-secondary and vocational-secondary levels of education rise as we move up through the wage distribution. Thirdly the returns to working in the private sector rise as we regress through higher quantiles. Thus, as found by Newell and Socha (op. cit.), the private sector seems to generate greater ceteris paribus wage inequality. The returns to white collar occupations all increase across the wage spectrum as do the returns to semi-skilled work. Additionally, the returns to long experience (over 20 years) are larger at the high end of the wage spectrum. Finally, the impact of local unemployment has no differential effect on wages across the wage spectrum. This casts doubt on conventional macroeconomic theories of increased wage inequality over this period. Thus, in summary, many wage determinants have larger proportional impacts on wages in the upper parts of the wage distribution. These results suggest that the available characteristics can account for more of overall wage inequality than they are allowed to by OLS. However, it is not clear that this would lead to greater explanation in the change in wage variance. The one discernable change is that at the lower percentiles, the wage advantage of having five years or more experience increases sharply. This seems to fit with the results from Table 15, which demonstrated a link between increased OLS residual wage inequality and an increased share of young workers.

Thirdly, there is evidence in Table 17 that part of wage inequality that is systematically related to education is expanding faster in the private sector. The estimated private sector wage premia to university and secondary education increase twice as fast 1998-2002 as their public sector counterparts. Note that the default group are those with only primary education. Again the evidence is that this group's relative position is worsened particularly in the private sector. Another notable result from Table 17 is the much greater negative effect from local unemployment rate on wages in the private sector. This mostly likely arises from the greater prevalence of national pay bargaining in the public sector, but may also reflect harder bargaining by private sector firms. Lastly, it clear that the rise in residual wage variance is larger in the private sector, which is consistent with the result reported in Table 15.

\section{Conclusions}

The first finding of the paper is that the large increase in wage variance in data from the Polish Labour Force Survey around the turn of the century reflects a real phenomenon rather than being due to the various deficiencies of the data. Secondly, we show that the increase in variance is associated with rising relative average wages, and ceteris paribus wage premia, for highly-educated professional and managerial workers as well as notably large rises in within-group variances for these groups. These shifts inform our understanding of the thickening of the upper tail of the wage distribution. There is also a notably large fall in the relative wage and rise in the within-group variance of wages of workers with only primary education. A standard variance decomposition by educational groups (Table 7) shows large contributions from university and primary educated workers to both the within-group and between group parts of the increase in overall wage variance 1998-2002.

Our OLS regression work supports these findings, illustrating that there were sharp increases in the returns to professional and managerial work, as well as an increase in 
the wage penalty imposed on primary-educated workers, after controlling for other characteristics. A regression-based decomposition of the change in wage variance (Table 14) apportions about one-half of the rise in wage inequality to these parameter shifts. By contrast changes in labour force characteristics have a small inequalityreducing effect. Our attempts to understand the other, residual, portion of the increased wage variation (see Tables 15, 16 and 17) suggest that this is greater in the private sector and that it is also are greater in skill-occupation groups that where the share of younger workers has increased more. The two most important groups in this respect were primary-educated workers in sales and skilled manual occupations.

In summary, these exercises suggest the proximate causes of the rise in wage inequality 1998-2002 were shifts in returns to education, increases in private sector employment and rises in the share of young people in some low-paid sectors of the labour market. What do these statistical results tell us about the deeper causes? Without data on taxes, we can say less about the impact of changes in the statutory minimum wage and tax changes. The thickening of the lower tail of the wage distribution is consistent with effects from the decline in the minimum wage. Similarly it is possible the rising inequality derives from the tax reforms. But these are probably not the major influences. The large rises in returns to highly-skilled occupations dominated by highly-educated workers and the fall in the return to primary-educated workers must be seen in the context of the very rapid structural and technological change of the Polish economy and the concurrent recession. There has undoubtedly been a large shift in labour demand away from manual workers to workers with higher levels of general education. Note how the share of skilled manual workers in the PLFS fell by 4 percentage points 1998-2002. This happened in tandem with, and partly via, the privatisation process and seems likely to be the core long-run driver of changes in the wage distribution at least until the supply of educated workers catches up with demand.

We have demonstrated that the private sector tends to pay more unequally than the state sector, and since there was a surge of privatisation 1998-2002, this contributed to the rise in wage inequality. It is also true that inequality, in the forms of hourly wage variance and of regression wage premia to education and occupation is consistently higher, and in the case of education premia, rose more quickly in the private sector data. Why are wages more and increasingly unequal in the private sector? Again, adjudicating between competing theories is beyond the power of the PFLS data, but the private sector-public sector gap in wage sensitivity to local unemployment helps our understanding. The lack public sector wage sensitivity to local unemployment is an interesting finding that naturally leads to speculation about the impact of differences in either the level of bargaining or in the level of social responsibility felt by managers. Whatever the reason for this phenomenon, in the period 1998-2002, the recession and the extension of privatisation combined to depress wages in higher unemployment regions more severely than previously. 


\section{References}

Freeman, R.B.(1982) "Union wage practices and wage dispersion within establishments”, Industrial \& Labor Relations Review, Vol. 36, pp.3-20.

Heckman, J. (1976), "The Common Structure of Statistical Models of Truncation, Sample Selection, and Limited Dependent Variables and a Simple Estimator for Such Models”, Annals of Economic and Social Measurement, 5, 1976, 475-492.

Keane, M. P. and E. Prasad (2002) "Changes in the Structure of Earnings During the Polish Transition”, IZA Discussion Paper No 496, May.

Koenker, R. and K. F. Hallock, (2001) "Quantile Regressions”, Journal of Economic Perspectives, 15: 4, 143-156.

Milanovic, B., (1999), "Explaining the increase in inequality during transition", Economics of Transition, 7 (2), 299-341.

Newell, A. and B. Reilly (2001), "The gender wage gap in the transition from communism: some empirical evidence”, Economic Systems, 25, 287-304.

Newell, A. and M. W. Socha (2005)” The Distribution of Wages in Poland, 19922002,” IZA Discussion Paper 1485.

OECD (2001), Taxing wages, OECD Paris.

OECD (2004), OECD Economic Surveys: Poland 2004, OECD Paris.

Oi, W. Y., and T. Idson (1999), "Firm Size and Wages” in Ashenfelter, O and D. Card (eds.) Handbook of Labor Economics Vol 3, North-Holland.

Popinski, W. (2006), 'Development of the Polish Labour Force Survey', Statistics in Transition, 7, 5, 1009-1030.

Rutkowski, J. (1996), 'High Skills Pay Off: The Changing Wage Structure During the Transition in Poland', Economics of Transition, 4, 89-111. 
Table 1: Gini coefficients for earnings, selected countries, 1989-2004.

\begin{tabular}{l|ccc}
\hline Country & 1989 & 1994 & 2004 \\
\hline Czech Republic & 0.204 & 0.260 & - \\
Hungary & 0.268 & 0.324 & - \\
Poland & 0.207 & 0.281 & 0.351 \\
Slovenia & 0.219 & 0.275 & 0.303 \\
& & & \\
Latvia & 0.244 & 0.325 & 0.321 \\
Lithuania & 0.260 & 0.390 & 0.394 \\
& & & \\
Romania & 0.155 & 0.277 & 0.358 \\
& & & \\
FYR Macedonia & - & 0.253 & 0.243 \\
Belarus & 0.234 & - & 0.338 \\
Moldova & 0.250 & 0.379 & 0.342 \\
Russia & 0.271 & 0.446 & 0.469 \\
Ukraine & 0.244 & - & 0.410 \\
& \multicolumn{4}{|c}{} \\
Armenia & 0.258 & 0.321 & 0.543 \\
Azerbaijan & 0.275 & 0.428 & - \\
Kazakhstan & 0.276 & - & 0.370 \\
Kyrgyzstan & 0.260 & 0.443 & 0.473 \\
\hline
\end{tabular}

Source : UNICEF's TransMONEE database, available at http://www.uniceficdc.org/resources/transmonee.html 
Table 2: Monthly wage distribution 1993-2004, from Polish Labour Force Survey

\begin{tabular}{l|lllll}
\hline & $\begin{array}{l}\text { 90/10 decile } \\
\text { ratio }\end{array}$ & $\begin{array}{l}90 / 50 \text { decile } \\
\text { ratio }\end{array}$ & $\begin{array}{l}50 / 10 \text { decile } \\
\text { ratio }\end{array}$ & Gini $(. s d)$. & $\begin{array}{l}\text { SD of log } \\
\text { monthly } \\
\text { wages }\end{array}$ \\
\hline 1993 & 2.61 & 1.60 & 1.63 & $0.227(.003)$ & 0.393 \\
1994 & 2.81 & 1.84 & 1.52 & $0.235(.003)$ & 0.402 \\
1995 & 2.62 & 1.81 & 1.45 & $0.236(.003)$ & 0.402 \\
1996 & 2.71 & 1.83 & 1.49 & $0.237(.003)$ & 0.404 \\
1997 & 2.62 & 1.69 & 1.55 & $0.235(.003)$ & 0.400 \\
1998 & 2.50 & 1.79 & 1.56 & $0.231(.003)$ & 0.395 \\
1999 & 2.88 & 1.87 & 1.54 & $0.238(.003)$ & 0.412 \\
2000 & 2.50 & 1.67 & 1.50 & $0.240(.003)$ & 0.417 \\
2001 & 2.76 & 1.78 & 1.55 & $0.257(.003)$ & 0.481 \\
2002 & 2.86 & 1.78 & 1.61 & $0.264(.004)$ & 0.495 \\
2003 & 2.98 & 1.85 & 1.61 & $0.262(.003)$ & 0.483 \\
2004 & 3.00 & 1.80 & 1.67 & $0.262(.003)$ & 0.496 \\
\hline
\end{tabular}

Notes: These statistics are derived from the 4th quarter survey for all years except 2002, for which the 2nd quarter survey is used.

Table 3 Illustrating the spikes in the wage recall data, November 1998 PLFS

\begin{tabular}{lc}
\hline Monthly wage in zlotys & \% of sample \\
\hline less than 400 & 0.9 \\
400 & 1.4 \\
401 to 449 & 1.3 \\
450 & 2.4 \\
$451-499$ & 2.1 \\
500 & 7.7 \\
$501-549$ & 2.6 \\
550 & 3.8 \\
$551-599$ & 2.3 \\
600 & 9.6 \\
$601-649$ & 1.8 \\
650 & 4.0 \\
$651-699$ & 1.9 \\
700 & 8.8 \\
more than 700 zlotys & 49.3 \\
\hline
\end{tabular}

Source: PLFS. 
Table 4: The increasing incidence of non-standard hours in the distribution of weekly hours, 1993-2004, from Polish Labour Force Survey

\begin{tabular}{l|ccc}
\hline & \% under 20 hours & \% under 30 hours & \% over 48 hours \\
\hline 1993 & 2.5 & 6.9 & 6.9 \\
1994 & 2.4 & 6.5 & 7.8 \\
& & & \\
1998 & 2.3 & 6.1 & 7.0 \\
1999 & 2.7 & 7.9 & 8.4 \\
2000 & 2.5 & 8.5 & 8.1 \\
2001 & 6.0 & 14.6 & 8.8 \\
2002 & 7.0 & 14.1 & 8.3 \\
2003 & 11.6 & 21.5 & 15.7 \\
2004 & 11.7 & 20.1 & 15.5 \\
\hline
\end{tabular}

Notes: These statistics are derived from the 4th quarter survey for all years except 2002, for which the 2nd quarter survey is used.

Table 5: Hourly wage distribution 1993-2004, from Polish Labour Force Survey

\begin{tabular}{l|lllll}
\hline & $\begin{array}{l}90 / 10 \text { decile } \\
\text { ratio }\end{array}$ & $\begin{array}{l}90 / 50 \text { decile } \\
\text { ratio }\end{array}$ & $\begin{array}{l}50 / 10 \text { decile } \\
\text { ratio }\end{array}$ & Gini (s.d.) & $\begin{array}{l}\text { s.d. of log } \\
\text { hourly } \\
\text { wages }\end{array}$ \\
\hline 1993 & 2.40 & 1.83 & 1.60 & $0.225(.003)$ & 0.431 \\
1994 & 3.00 & 1.90 & 1.58 & $0.255(.003)$ & 0.434 \\
& & & & & \\
1998 & 2.90 & 1.90 & 1.52 & $0.248(.003)$ & 0.430 \\
1999 & 3.08 & 1.93 & 1.60 & $0.267(.004)$ & 0.459 \\
2000 & 3.09 & 1.96 & 1.58 & $0.272(.004)$ & 0.465 \\
2001 & 3.33 & 1.78 & 1.55 & $0.288(.004)$ & 0.497 \\
2002 & 2.86 & 1.78 & 1.61 & $0.276(.004)$ & 0.509 \\
2003 & 2.98 & 1.85 & 1.61 & $0.300(.004)$ & 0.511 \\
2004 & 3.00 & 1.80 & 1.67 & $0.298(.004)$ & 0.513 \\
\hline
\end{tabular}

Notes: These statistics are derived from the 4th quarter survey for all years except 2002, for which the 2nd quarter survey is used. 
Table 6: Selected Descriptive Statistics for Employees, 1998 and 2002

\begin{tabular}{|c|c|c|c|c|c|}
\hline & Proportion who are: & 1998 & 1998 & 2002 & 2002 \\
\hline & & all & $\begin{array}{l}\text { give } \\
\text { wage }\end{array}$ & all & $\begin{array}{l}\text { give } \\
\text { wage }\end{array}$ \\
\hline \multirow{6}{*}{ Education } & Married & 0.75 & 0.75 & 0.74 & 0.74 \\
\hline & Reveal their wages & 0.82 & & 0.66 & \\
\hline & Full-time student & 0.05 & 0.06 & 0.06 & 0.06 \\
\hline & University & 0.13 & 0.13 & 0.15 & 0.12 \\
\hline & Lower Vocational & 0.38 & 0.37 & 0.34 & 0.36 \\
\hline & Primary & 0.11 & 0.11 & 0.10 & 0.10 \\
\hline \multirow{6}{*}{ Industry, sector and size } & Ag, Mining, Manufacture & 0.34 & 0.34 & 0.32 & 0.34 \\
\hline & Trade and repair & 0.14 & 0.14 & 0.16 & 0.16 \\
\hline & Finance and real estate & 0.06 & 0.06 & 0.07 & 0.07 \\
\hline & Private Sector & 0.41 & 0.41 & 0.56 & 0.58 \\
\hline & Firm size 1 to 20 & 0.30 & 0.29 & 0.32 & 0.29 \\
\hline & Firm size over 100 & 0.40 & 0.38 & 0.34 & 0.35 \\
\hline \multirow{3}{*}{ Occupation } & Professional & 0.12 & 0.12 & 0.12 & 0.08 \\
\hline & Sales & 0.10 & 0.10 & 0.13 & 0.13 \\
\hline & Skilled manual & 0.26 & 0.26 & 0.22 & 0.23 \\
\hline \multirow{4}{*}{ Experience and tenure } & & & & & \\
\hline & Under 5 years experience & 0.15 & 0.15 & 0.13 & 0.12 \\
\hline & Over 20 years experience & 0.45 & 0.45 & 0.50 & 0.50 \\
\hline & Over 10 years tenure & 0.39 & 0.39 & 0.37 & 0.38 \\
\hline
\end{tabular}

Note. From 2002 the firm size categories change as follows: 1 to 20 becomes 1 to 19 . Here and throughout potential experience is measured as equal to age -7 - years in education.

Table 7 Wage gaps and wage variance by occupation, education and sector

\begin{tabular}{lcccc}
\hline & \multicolumn{2}{c}{1998} & & \\
& $\bar{w}_{i}-\bar{w}$ & $\sigma$ & $\bar{w}_{i}-\bar{w}$ & $\sigma$ \\
\hline Occupation & & & & \\
\hline Professional & 0.45 & 0.43 & 0.45 & 0.52 \\
Managerial & 0.48 & 0.42 & 0.60 & 0.50 \\
Technical & 0.08 & 0.38 & 0.18 & 0.43 \\
Clerical & -0.04 & 0.33 & 0.03 & 0.36 \\
Sales & -0.30 & 0.32 & -0.28 & 0.37 \\
Skilled manual & -0.07 & 0.36 & -0.08 & 0.41 \\
Semi-skilled & -0.02 & 0.36 & -0.01 & 0.40 \\
Unskilled & -0.30 & 0.28 & -0.30 & 0.32 \\
\hline Education & & & & \\
\hline University & 0.50 & 0.43 & 0.53 & 0.52 \\
Gn. Secondary & 0.01 & 0.39 & 0.02 & 0.42 \\
Lr. Vocational & -0.13 & 0.35 & -0.16 & 0.40 \\
Primary & -0.22 & 0.35 & -0.34 & 0.52 \\
\hline Sector & & & & \\
\hline Private & -0.09 & 0.43 & -0.11 & 0.51 \\
Public & 0.06 & 0.42 & 0.14 & 0.48 \\
\hline
\end{tabular}


Table 8 : Impact of non-revelation on the occupational and wage distribution of employees, 1998-2004

\begin{tabular}{|c|c|c|c|c|}
\hline & \multicolumn{2}{|c|}{$\begin{array}{l}\text { Share of managers and } \\
\text { professionals }\end{array}$} & \multirow[b]{2}{*}{$\begin{array}{c}\text { Actual s.d. of } \\
\text { log hourly } \\
\text { wages }\end{array}$} & \multirow[b]{2}{*}{$\begin{array}{l}\text { Counterfactual } \\
\text { s.d. of log } \\
\text { hourly wages }\end{array}$} \\
\hline & $\begin{array}{l}\text { Among wage } \\
\text { revealers }\end{array}$ & $\begin{array}{l}\text { Among } \\
\text { employees }\end{array}$ & & \\
\hline 1998 & 0.161 & 0.168 & 0.430 & 0.432 \\
\hline 2000 & 0.163 & 0.176 & 0.465 & 0.468 \\
\hline 2002 & 0.153 & 0.177 & 0.509 & 0.518 \\
\hline 2004 & 0.178 & 0.207 & 0.513 & 0.524 \\
\hline
\end{tabular}

Table 9 Changes at the tails of the hourly wage distribution

\begin{tabular}{lcc}
\hline $\begin{array}{l}\text { Percent of wage respondents earning X\% or less } \\
\text { than the average hourly wage: }\end{array}$ & 1998 & \\
\hline $40 \%$ & & 2002 \\
$50 \%$ & 5.1 & 9.9 \\
$60 \%$ & 19.5 & 22.3 \\
$150 \%$ & 88 & 86 \\
$200 \%$ & 96 & 94 \\
\hline
\end{tabular}

Table 10 Estimated characteristics of the population of working age, 1994-2004

\begin{tabular}{l|cccc}
\hline Proportion who are: & $1994 r 4$ & $1998 r 4$ & $2002 r 2$ & $2004 r 4$ \\
\hline Women & 0.491 & 0.489 & 0.491 & 0.510 \\
Household head & 0.384 & 0.363 & 0.354 & 0.362 \\
Married & 0.668 & 0.630 & 0.606 & 0.612 \\
Ed-University & 0.073 & 0.079 & 0.088 & 0.116 \\
Ed-Post Sec. & 0.027 & 0.026 & 0.030 & 0.030 \\
Ed-General Sec. & 0.196 & 0.217 & 0.209 & 0.206 \\
Ed-Vocational Sec. & 0.070 & 0.077 & 0.086 & 0.097 \\
Ed-Lower Vocational & 0.302 & 0.311 & 0.310 & 0.295 \\
Ed-Primary or lower & 0.318 & 0.283 & 0.272 & 0.254 \\
Employee & 0.414 & 0.399 & 0.365 & 0.362 \\
Unemployed & 0.104 & 0.118 & 0.146 & 0.119 \\
Employed & 0.586 & 0.552 & 0.515 & 0.506 \\
Participants & 0.680 & 0.670 & 0.661 & 0.625 \\
Aged 15 to 20 & 0.162 & 0.166 & 0.150 & 0.122 \\
Aged 21 to 25 & 0.099 & 0.113 & 0.120 & 0.115 \\
Aged 26 to30 & 0.091 & 0.094 & 0.101 & 0.099 \\
Aged 31 to35 & 0.110 & 0.087 & 0.088 & 0.093 \\
Aged 36 to 40 & 0.137 & 0.108 & 0.088 & 0.083 \\
Aged 41 to 45 & 0.132 & 0.131 & 0.119 & 0.099 \\
Aged 46 to 50 & 0.094 & 0.121 & 0.129 & 0.118 \\
Aged 51 to 55 & 0.073 & 0.091 & 0.114 & 0.111 \\
Aged 56 to 60 & 0.072 & 0.063 & 0.066 & 0.088 \\
Sample Size & 43666 & 37039 & 38132 & 38132 \\
\hline Sour Aus
\end{tabular}

Source: Author's calculations from the PLFS. 
Table 11: Descriptive Statistics for Employees

\begin{tabular}{l|cccc}
\hline Proportion who are: & $1994 r 4$ & $1998 r 4$ & $2002 r 2$ & $2004 r 4$ \\
\hline Women & 0.47 & 0.47 & 0.48 & 0.47 \\
Household head & 0.50 & 0.47 & 0.50 & 0.49 \\
Married & 0.78 & 0.75 & 0.74 & 0.73 \\
Ed-University & 0.13 & 0.13 & 0.15 & 0.22 \\
Ed-Post Sec. & 0.05 & 0.04 & 0.05 & 0.4 \\
Ed-General Sec. & 0.27 & 0.28 & 0.28 & 0.26 \\
Ed-Vocational Sec. & 0.07 & 0.06 & 0.08 & 0.08 \\
Ed-Lower Vocational & 0.35 & 0.38 & 0.34 & 0.31 \\
Ed-Primary & 0.14 & 0.11 & 0.10 & 0.08 \\
Agriculture & 0.04 & 0.03 & 0.03 & 0.03 \\
Mining & 0.05 & 0.03 & 0.02 & 0.02 \\
Manufacturing & 0.29 & 0.28 & 0.27 & 0.25 \\
Utilities & 0.03 & 0.02 & 0.02 & 0.02 \\
Construction & 0.07 & 0.08 & 0.06 & 0.07 \\
Trade and repair & 0.11 & 0.14 & 0.16 & 0.16 \\
Transport & 0.07 & 0.07 & 0.07 & 0.07 \\
Finance and real estate & 0.05 & 0.06 & 0.07 & 0.08 \\
Public services and defense & 0.30 & 0.29 & 0.30 & 0.30 \\
Private Sector & 0.25 & 0.41 & 0.56 & 0.59 \\
Firm size 1 to 20 & 0.26 & 0.30 & 0.32 & 0.31 \\
Firm size 21 to 50 & 0.17 & 0.17 & 0.18 & 0.18 \\
Firm size 51 to 100 & 0.13 & 0.13 & 0.16 & 0.16 \\
Firm size over 100 & 0.45 & 0.40 & 0.34 & 0.35 \\
Professional & 0.13 & 0.12 & 0.13 & 0.16 \\
Managerial & 0.05 & 0.04 & 0.05 & 0.05 \\
Technical & 0.16 & 0.15 & 0.16 & 0.15 \\
Clerical & 0.09 & 0.10 & 0.10 & 0.09 \\
Sales & 0.08 & 0.11 & 0.12 & 0.12 \\
Farm workers & 0.01 & 0.01 & 0.01 & 0.01 \\
Skilled manual & 0.26 & 0.25 & 0.21 & 0.20 \\
Semi-skilled manual & 0.11 & 0.11 & 0.11 & 0.12 \\
Unskilled & 0.11 & 0.11 & 0.11 & 0.10 \\
Reveal their wages & 0.89 & 0.82 & 0.66 & 0.63 \\
Full-time student & 0.01 & 0.05 & 0.06 & 0.08 \\
Under 5 years experience & 0.12 & 0.15 & 0.13 & 0.11 \\
5 to 10 years experience & 0.13 & 0.13 & 0.13 & 0.14 \\
10 to 20 years experience & 0.33 & 0.28 & 0.25 & 0.26 \\
Over 20 years experience & 0.43 & 0.45 & 0.50 & 0.47 \\
Tenure less than a year & 0.15 & 0.15 & 0.14 & 0.17 \\
1 to 5 years tenure & 0.23 & 0.28 & 0.30 & 0.28 \\
5 to 10 years tenure & 0.18 & 0.18 & 0.19 & 0.20 \\
Over 10 years tenure & 0.44 & 0.39 & 0.37 & 0.36 \\
\hline
\end{tabular}

Note. From 2002 the firm size categories change as follows: 1 to 20 becomes 1 to $19 ; 21$ to 50 becomes 20 to 49 ; 51 to 100 becomes 50 to 100 . Here and throughout potential experience is measured as equal to age -7 - years in education 
Table 12: Ordinary least squares estimates of augmented Mincerian hourly earnings equations, Poland 1994-2004.

\begin{tabular}{|c|c|c|c|c|}
\hline & 1994 & 1998 & 2002 & 2004 \\
\hline Woman & -0.15 & -0.15 & -0.13 & -0.13 \\
\hline Household head & 0.07 & 0.07 & 0.11 & 0.10 \\
\hline Married & 0.03 & 0.03 & 0.05 & 0.07 \\
\hline Ed-university & 0.42 & 0.42 & 0.48 & 0.42 \\
\hline Ed-post secondary & 0.18 & 0.18 & 0.24 & 0.22 \\
\hline Ed-general secondary & 0.13 & 0.16 & 0.23 & 0.21 \\
\hline Ed-vocational secondary & 0.14 & 0.18 & 0.26 & 0.25 \\
\hline Ed-lower vocational & 0.06 & 0.07 & 0.13 & 0.13 \\
\hline Ind-agriculture & -0.09 & $-0.04^{*}$ & $0.01^{\mathrm{NS}}$ & $-0.04^{\mathrm{NS}}$ \\
\hline Ind-mining & 0.37 & 0.31 & 0.30 & 0.26 \\
\hline Ind-manufacturing & $0.02^{\mathrm{NS}}$ & 0.04 & $0.02^{\mathrm{NS}}$ & $0.01^{\mathrm{NS}}$ \\
\hline Ind -utilities & 0.25 & 0.20 & 0.15 & 0.20 \\
\hline Ind -construction & $0.03^{*}$ & 0.10 & 0.10 & 0.07 \\
\hline Ind-trade and repair & $-0.03^{*}$ & $0.02^{\mathrm{NS}}$ & $0.01^{\mathrm{NS}}$ & $0.01^{\mathrm{NS}}$ \\
\hline Ind-transport & 0.04 & 0.08 & 0.09 & 0.12 \\
\hline Ind-finance and real estate & 0.08 & 0.11 & 0.08 & $0.02^{\mathrm{NS}}$ \\
\hline Holds a temporary contract & -0.12 & -0.12 & -0.08 & -0.07 \\
\hline Private Sector & 0.11 & 0.08 & $0.01^{\mathrm{NS}}$ & $0.01^{\mathrm{NS}}$ \\
\hline Firm size: tiny & -0.11 & -0.08 & -0.08 & -0.07 \\
\hline Firm size: small & -0.04 & -0.04 & $-0.01^{\mathrm{NS}}$ & $0.03^{\mathrm{NS}}$ \\
\hline Firm size: large & $-0.00^{\mathrm{NS}}$ & $0.01^{\mathrm{NS}}$ & $0.02^{\mathrm{NS}}$ & $0.02 *$ \\
\hline Firm size: very large & 0.07 & 0.06 & 0.08 & 0.06 \\
\hline Occ-professional & 0.15 & 0.22 & 0.35 & 0.44 \\
\hline Occ-managerial & 0.30 & 0.37 & 0.50 & 0.43 \\
\hline Occ-technical & 0.12 & 0.15 & 0.20 & 0.16 \\
\hline Occ-clerical & $0.03 *$ & 0.08 & 0.11 & 0.05 \\
\hline Occ-sales & -0.05 & -0.04 & -0.05 & -0.05 \\
\hline Occ-farm workers & $-0.00^{\mathrm{NS}}$ & $-0.03^{\mathrm{NS}}$ & -0.09 & $0.08^{\mathrm{NS}}$ \\
\hline Occ-semi-skilled & $0.03 *$ & 0.04 & 0.05 & 0.04 \\
\hline Occ-unskilled & -0.13 & -0.09 & -0.09 & -0.11 \\
\hline Full-time student & $0.06^{\mathrm{NS}}$ & -0.12 & -0.09 & -0.07 \\
\hline 5 to 10 years experience & 0.05 & 0.08 & 0.11 & 0.16 \\
\hline 10 to 20 year experience & 0.09 & 0.07 & 0.12 & 0.17 \\
\hline Over 20 year experience & 0.11 & 0.10 & 0.10 & 0.15 \\
\hline 1 to 5 years tenure & 0.05 & 0.04 & 0.05 & 0.07 \\
\hline 5 to 10 years tenure & 0.03 & 0.08 & 0.09 & 0.09 \\
\hline Over 10 years tenure & 0.06 & 0.09 & 0.11 & 0.15 \\
\hline worked over 48 hours & -0.17 & -0.14 & -0.16 & -0.18 \\
\hline worked under 35 hours & 0.40 & 0.37 & 0.29 & 0.26 \\
\hline Urban wojvodship & 0.24 & 0.24 & 0.40 & 0.17 \\
\hline Wojvodship unemployment rate & -0.28 & -0.69 & -0.59 & -1.31 \\
\hline $\bar{R}^{2}$ & 0.46 & 0.49 & 0.48 & 0.53 \\
\hline see & 0.32 & 0.31 & 0.37 & 0.35 \\
\hline $\mathrm{N}$ & 15615 & 15027 & 9910 & 8693 \\
\hline
\end{tabular}

Note: all coefficients are conventionally significant at the $1 \%$ level except those marked *, which are significant at the $5 \%$ level and those marked ${ }^{\mathrm{NS}}$, which are not significant. 
Table 13: ML Heckman wage equation estimates, 1998r4 and 2002r2

\begin{tabular}{|c|c|c|c|c|c|}
\hline Wage equation & $1998 q 4$ & $2002 q 2$ & Selection equation & $1998 q 4$ & $2002 q 2$ \\
\hline Woman & -0.13 & -0.11 & Woman & -0.11 & $-0.02^{\mathrm{NS}}$ \\
\hline Household head & 0.06 & 0.09 & Head of Household & 0.26 & 0.37 \\
\hline Married & 0.03 & 0.04 & Married & 0.08 & 0.14 \\
\hline Ed-university & 0.41 & 0.47 & Ed-university & 0.48 & 0.40 \\
\hline Ed-post secondary & 0.18 & 0.22 & Ed-post secondary & 0.83 & 0.76 \\
\hline Ed-general secondary & 0.13 & 0.20 & Ed-general secondary & 0.66 & 0.56 \\
\hline Ed-vocational secondary & 0.16 & 0.23 & Ed-vocational secondary & 0.38 & 0.36 \\
\hline Ed-lower vocational & 0.05 & 0.10 & Ed-lower vocational & 0.53 & 0.39 \\
\hline Ind-agriculture & $-0.08 *$ & $-0.04^{\mathrm{NS}}$ & Aged 21 to 25 & 0.81 & 0.80 \\
\hline Ind-mining & 0.29 & 0.28 & Aged 26 to30 & 0.93 & 1.00 \\
\hline Ind-manufacturing & $0.02 *$ & $-0.00 *$ & Aged 31 to35 & 0.87 & 0.95 \\
\hline Ind -utilities & 0.17 & 0.12 & Aged 36 to 40 & 0.91 & 0.95 \\
\hline Ind -construction & -0.06 & 0.04 & Aged 41 to 45 & 0.93 & 0.94 \\
\hline Ind-trade and repair & $-0.02^{\mathrm{NS}}$ & $-0.00^{N S}$ & Aged 46 to 50 & 0.84 & 0.85 \\
\hline Ind-transport & 0.05 & 0.05 & Aged 51 to 55 & 0.50 & 0.66 \\
\hline Ind-finance and r.e. & 0.05 & $0.05^{*}$ & Aged 56 to 60 & $-0.09 *$ & $0.20 *$ \\
\hline temporary contract & -0.11 & -0.06 & Aged over 61 & -1.19 & -0.75 \\
\hline Private Sector & 0.06 & $-0.00^{\mathrm{NS}}$ & Vague & 0.64 & 0.67 \\
\hline Firm size 1 to $5^{1}$ & -0.08 & -0.07 & Local unemployment rate & $0.34 *$ & $0.31^{\mathrm{NS}}$ \\
\hline Firm size 6 to $20^{1}$ & -0.03 & $-0.00^{\mathrm{NS}}$ & works in finance & 0.52 & 0.48 \\
\hline Firm size 51 to $100^{1}$ & $0.02^{\text {NS }}$ & $0.02^{\mathrm{NS}}$ & professional occupation & 0.85 & 0.64 \\
\hline Firm size over $100^{1}$ & 0.04 & 0.06 & $\hat{\rho}$ & $-0.11 *$ & -0.11 \\
\hline Occ-professional & 0.32 & 0.42 & $\hat{\sigma}$ & 0.32 & 0.39 \\
\hline Occ-managerial & 0.36 & 0.47 & LR test $(\rho=0), \chi^{2}(1)$ & $6.3^{*}$ & $5.4^{*}$ \\
\hline Occ-technical & 0.13 & 0.19 & Wald chi2(40) & 8930.7 & 5540.5 \\
\hline Occ-clerical & 0.07 & 0.11 & Log likelihood & -27927 & -23766 \\
\hline Occ-sales & -0.06 & $-0.06 *$ & $\mathrm{~N}$ & 54405 & 48009 \\
\hline Occ-farm workers & $-0.04^{\mathrm{NS}}$ & $-0.09^{N S}$ & Uncensored obs & 15027 & 9911 \\
\hline Occ-semi-skilled & 0.04 & 0.05 & $\lambda$ & -.035 & -.041 \\
\hline Occ-unskilled & -0.10 & -0.08 & & & \\
\hline Full-time student & -0.08 & $-0.05 *$ & & & \\
\hline 5 to 10 years experience & 0.08 & 0.11 & & & \\
\hline 10 to 20 year experience & 0.07 & 0.13 & & & \\
\hline Over 20 year experience & 0.09 & 0.13 & & & \\
\hline 1 to 5 years tenure & 0.04 & 0.05 & & & \\
\hline 5 to 10 years tenure & 0.08 & 0.10 & & & \\
\hline Over 10 years tenure & 0.11 & 0.11 & & & \\
\hline Urban wojvodship & 0.36 & 0.16 & & & \\
\hline Local unemployment rate & -0.69 & -0.64 & & & \\
\hline
\end{tabular}

Notes. Estimation is by Heckman's (1976) maximum likelihood method as programmed in Stata 9. All coefficients are conventionally significant at the $1 \%$ level except those marked *, which are significant at the $5 \%$ level and those marked ${ }^{\mathrm{NS}}$, which are not significant. 
Table 14: Decomposing the change in the variances of log wages 1994-2002

\begin{tabular}{llllll}
\hline $\begin{array}{l}\text { Estimation } \\
\text { method }\end{array}$ & Period & $\begin{array}{l}\text { Total } \\
\text { change }\end{array}$ & $\begin{array}{l}\text { Due to } \\
\text { coefficients }\end{array}$ & $\begin{array}{l}\text { Due to } \\
\text { characteristics }\end{array}$ & $\begin{array}{l}\text { Due to } \\
\text { omitted } \\
\text { characteristics } \\
\text { and their } \\
\text { coefficients }\end{array}$ \\
\hline OLS & $1994-$ & -0.0103 & 0.0046 & -0.0020 & -0.0129 \\
OLS & 1998 & & & & 0.0458 \\
& $1998-$ & 0.0736 & 0.0407 & -0.0130 & \\
\hline
\end{tabular}

Source: author's calculations from PLFS data.

Table 15: Explaining the pattern in wage residual variance growth across educational/occupational groups 1998-2002

(Dependent variable: The change, 98-02, in the wage residual standard error, $\Delta \sigma_{i}$.) coefficient (|t-ratio|)

$\Delta$ share of workers with less than five 1.02 (5.7)

years of potential experience ${ }_{i}$

1998 share of private sector workers $\quad 0.14(2.4)$

1998 share of women $\quad 0.10(2.5)$

constant $\quad-0.02(0.5)$

$R^{2} \quad 0.67$

$N \quad 20$

see $\quad 0.038$

See text for discussion 
Table 16: Selected quantile wage regressions results for 1998 and 2002.

\begin{tabular}{|c|c|c|c|c|c|}
\hline 1998 results & $q 10$ & $q 25$ & $q 50$ & $q 75$ & $q 90$ \\
\hline Woman & -0.10 & -0.12 & -0.15 & -0.16 & -0.17 \\
\hline Ed-university & 0.32 & 0.35 & 0.39 & 0.46 & 0.52 \\
\hline d-post secondary & 0.17 & 0.12 & 0.14 & 0.22 & 0.27 \\
\hline d-general secondary & 0.13 & 0.11 & 0.12 & 0.16 & 0.18 \\
\hline d-lower vocational & 0.07 & 0.04 & 0.05 & 0.06 & 0.06 \\
\hline Private Sector & 0.03 & 0.05 & 0.05 & 0.06 & $0.10^{*}$ \\
\hline Occ-professional & 0.24 & 0.27 & 0.37 & 0.44 & 0.47 \\
\hline cc-m & 0.24 & 0.29 & 0.38 & 0.45 & 0.50 \\
\hline hnical & 0.08 & 0.10 & 0.14 & 0.17 & 0.22 \\
\hline cc-clerical & $0.05 *$ & 0.06 & 0.08 & 0.09 & 0.11 \\
\hline 5 to 10 years experience & 0.05 & 0.05 & 0.06 & 0.10 & 0.10 \\
\hline 10 to & $0.05^{*}$ & 0.05 & 0.06 & 0.08 & 0.09 \\
\hline Over 20 year e & $0.07 *$ & 0.07 & 0.08 & 0.11 & 0.12 \\
\hline Local unemployment rate & -0.52 & -0.49 & -0.75 & -0.68 & -0.85 \\
\hline 2002 results & $q 10$ & $q 25$ & $q 50$ & $q 75$ & $q 90$ \\
\hline Woman & -0.08 & -0.10 & -0.13 & -0.14 & -0.15 \\
\hline Ed-university & 0.45 & 0.41 & 0.41 & 0.43 & 0.49 \\
\hline Ed-po & 0.27 & 0.20 & 0.17 & 0.19 & 0.26 \\
\hline Ed-general secondary & 0.27 & 0.18 & 0.15 & 0.16 & 0.19 \\
\hline Ed-lower vocational & 0.16 & 0.08 & 0.05 & 0.06 & 0.07 \\
\hline Private Sector & -0.08 & -0.05 & $-0.01^{\mathrm{NS}}$ & $0.01^{\mathrm{NS}}$ & $0.06 *$ \\
\hline Occ-professional & 0.30 & 0.32 & 0.46 & 0.53 & 0.57 \\
\hline Occ-managerial & 0.31 & 0.35 & 0.42 & 0.56 & 0.66 \\
\hline ical & 0.10 & 0.12 & 0.18 & 0.24 & 0.29 \\
\hline Occ-clerical & 0.11 & 0.08 & 0.09 & 0.12 & 0.14 \\
\hline 5 to 10 years experience & 0.12 & 0.08 & 0.04 & 0.06 & 0.11 \\
\hline & 0.10 & 0.07 & 0.08 & 0.11 & 0.15 \\
\hline Over 20 year experience & 0.09 & 0.07 & 0.10 & 0.09 & 0.18 \\
\hline Local unemployment rate & $-0.26^{\mathrm{NS}}$ & $-0.21^{\mathrm{NS}}$ & -0.44 & -0.72 & -0.93 \\
\hline
\end{tabular}

Notes. All coefficients are conventionally significant at the $1 \%$ level except those marked *, which are significant at the $5 \%$ level and those marked ${ }^{\mathrm{NS}}$, which are not significant.

Table 17. Key wage regression parameters by sector, 1998 and 2002

\begin{tabular}{lcccc}
\hline & \multicolumn{2}{c}{ Private Sector } & \multicolumn{2}{c}{ Public Sector } \\
& 1998 & 2002 & 1998 & 2002 \\
\hline Conpleted education (default: Primary) & & & & \\
University & 0.45 & 0.53 & 0.40 & 0.44 \\
General secondary & 0.15 & 0.26 & 0.15 & 0.19 \\
$\begin{array}{l}\text { Occupation (default: Skilled manual) } \\
\text { Professional }\end{array}$ & 0.31 & 0.38 & 0.14 & 0.22 \\
Manager & 0.41 & 0.51 & 0.33 & 0.42 \\
Local unemployment rate & -1.04 & -1.05 & 0.00 & -0.41 \\
& 0.31 & 0.38 & 0.28 & 0.32 \\
\hline Standard error of the equation & & & &
\end{tabular}

Source: Newell and Socha (2005). Each cell is a coefficient from a wage regression using the PLFS data and very similar specifications to those in Table 12. 
Chart 1: Wage frequencies from the 1998r4 and 2002r2 PLFS.

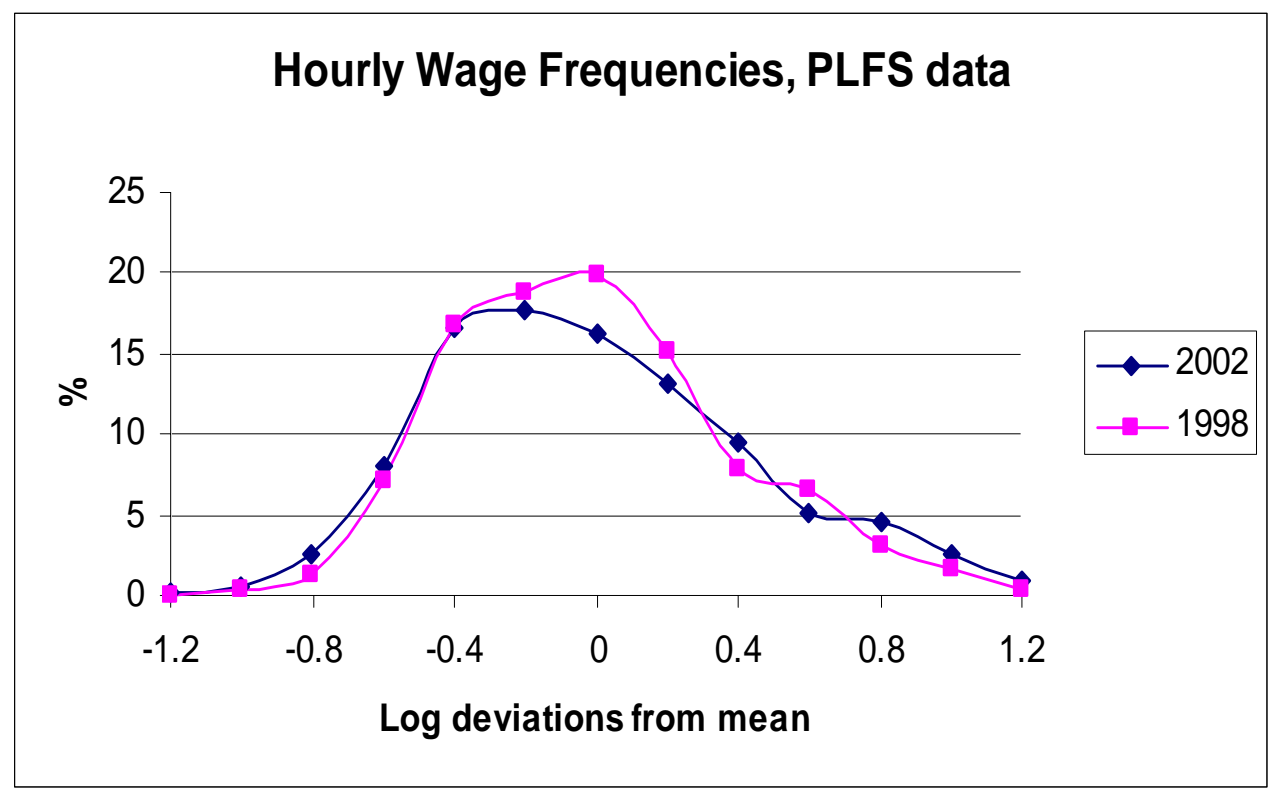

